TITLE:

\title{
ON TWO FORMS OF CERAPUS TUBULARIS, A TUBE DWELLING AMPHIPODA, FROM SHALLOW WATERS OF JAPAN
}

AUTHOR(S):

Morino, Hiroshi

\section{CITATION:}

Morino, Hiroshi. ON TWO FORMS OF CERAPUS TUBULARIS, A TUBE DWELLING

AMPHIPODA, FROM SHALLOW WATERS OF JAPAN. PUBLICATIONS OF THE SETO MARINE BIOLOGICAL LABORATORY 1976, 23(1-2): 179-189

ISSUE DATE:

1976-07-31

URL:

http://hdl.handle.net/2433/175915

RIGHT: 


\title{
ON TWO FORMS OF CERAPUS TUBULARIS, A TUBE DWELLING AMPHIPODA, FROM SHALLOW WATERS OF JAPAN ${ }^{1}$
}

\author{
HIROSHI MORINO ${ }^{2)}$ \\ Seto Marine Biological Laboratory \\ With Text-figures $1-8$ and Table 1
}

While examining the benthic amphipods from the shallow water of Wakasa Bay, Japan Sea, I noticed several specimens inhabiting the elegantly formed tube that was perfectly cylindrical and had leathery texture. Later, Mr. Yanagisawa of our laboratory collected some tubicolous amphipods alive from the bottom of Tanabe Bay, Wakayama Ken. They were at times swimming about with the tube, and their morphology and tube closely resembled to those from Wakasa Bay. Recently, Mr. Nishikawa of our laboratory also offered me nest-carrying amphipods which he found on the intertidal rocky shore of Uematsu in Kushimoto, Wakayama Ken. They were also swimming around with their nest which was, however, made of some pieces of foreign materials, and their body shape was somewhat different in appearance from that of the preceding specimens.

These animals from three localities have peculiar pereiopods, pleopods and uropods in common, which easily resulted in the identification as Cerapus species. The genus Cerapus comprises six species at present. In 1962, Barnard has established a new synonymy by amalgamating $C$. abditus Templeton, $C$. longirostris Shen and C. erae Bulycheva to $C$. tubularis Say, and recognized five valid species. After that, Kudrjashov (1973) described a new Cerapus species, C. comparativus. Among these six species, the present specimens are all identified as Cerapus tubularis. On consulting the original descriptions available, it is still noticed that the specimens from Wakasa Bay and Tanabe Bay well accord with C. erae Bulycheva, and those from Uematsu seems to be related closely to $C$. longirostris Shen, both reported from the Far Eastern waters in the Pacific Ocean.

For the reason stated later, these specimens from three localities should be treated as belonging to the same species, Cerapus tubularis sensu Barnard. For the convenience's sake, the animals from Wakasa and Tanabe Bay will be referred to as Form A, and those from Uematsu as Form B. In this paper, exact comparisons

1) Contributions from the Seto Marine Biological Laboratory, No. 620.

2) Present address: Department of Biology, Ibaraki University, Mito 310 Japan.

Publ. Seto Mar. Biol. Lab., XXIII (1/2), 179-189, 1976.

(Article 13) 
are made between these two Forms to learn whether the Barnard's treatment to include $C$. longirostris and $C$. erae in C. tubularis is really reasonable. So far in Japan, Nagata (1965) reported specimens of $C$. tubularis from the Seto Inland Sea, which fit well to Form A judging from his figures.

I would like to express my sincere gratitude to Mr. I. Hayashi of Fisheries Department of Kyoto University, Mr. Y. Yanagisawa and Mr. T. Nishikawa of the Seto Marine Biological Laboratory, for their generosity in affording me those interesting specimens. My thanks are also due to Prof. T. Tokioka, Dr. E. Harada of the Laboratory for critical reading of the manuscript and discussions. Dr. K. Nagata of the Nansei Regional Fisheries Station kindly made some literature available to me, to whom I am indebted.

\section{Cerapus tubularis Say sensu Barnard}

Cerapus tubularis Say 1817, Barnard 1962, pp. 61-63, figs. 28-29.

Stebbing 1906, pp. 667-668.

Kunkel 1918, pp. 160-161, fig. 48.

C. abditus Templeton 1836, Stebbing 1906, pp. 668-669.

$$
\text { 1910, pp. 616-618, Pl. 55A. }
$$

Pirlot, 1938, pp. 349 352, figs. 157-158.

C. longirostris Shen 1936, pp. 265-272, figs. 1-5.

C. erae Bulycheva 1952, pp. 248-249, fig. 39 .

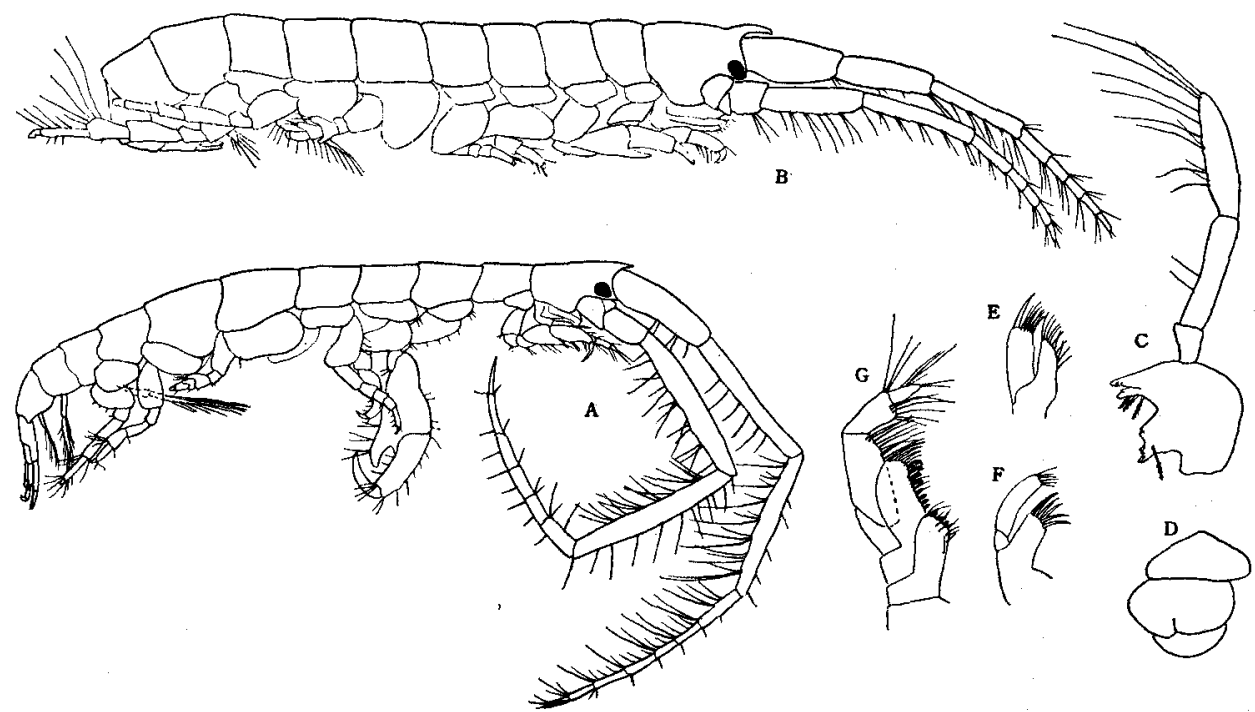

Text-fig. 1. A, Form A $(\times 16.5)$; B, Form B $(\times 16.5)$; C, mandible of Form A $(\times 48)$; D, upper lip of Form A $(\times 48)$; E, 2nd maxilla of Form A $(\times 48) ;$ F, 1st maxilla of Form A $(\times 48) ; G$, maxilliped of Form A $(\times 48)$. A, C-G, from Tanabe Bay, May 21, 1973; B, from Kushimoto, December 27, 1973. 


\section{Material Examined}

Eight specimens from off the mouth of Yura River, Wakasa Bay, collected by Mr. I. Hayashi, on May 19, 1972. 22 specimens from Rinkai, Tanabe Bay, collected by Mr. Y. Yanagisawa, on May 21, 1973. 12 specimens from Uematsu, Kushimoto, collected by Mr. T. Nishikawa, on December 27, 1973.

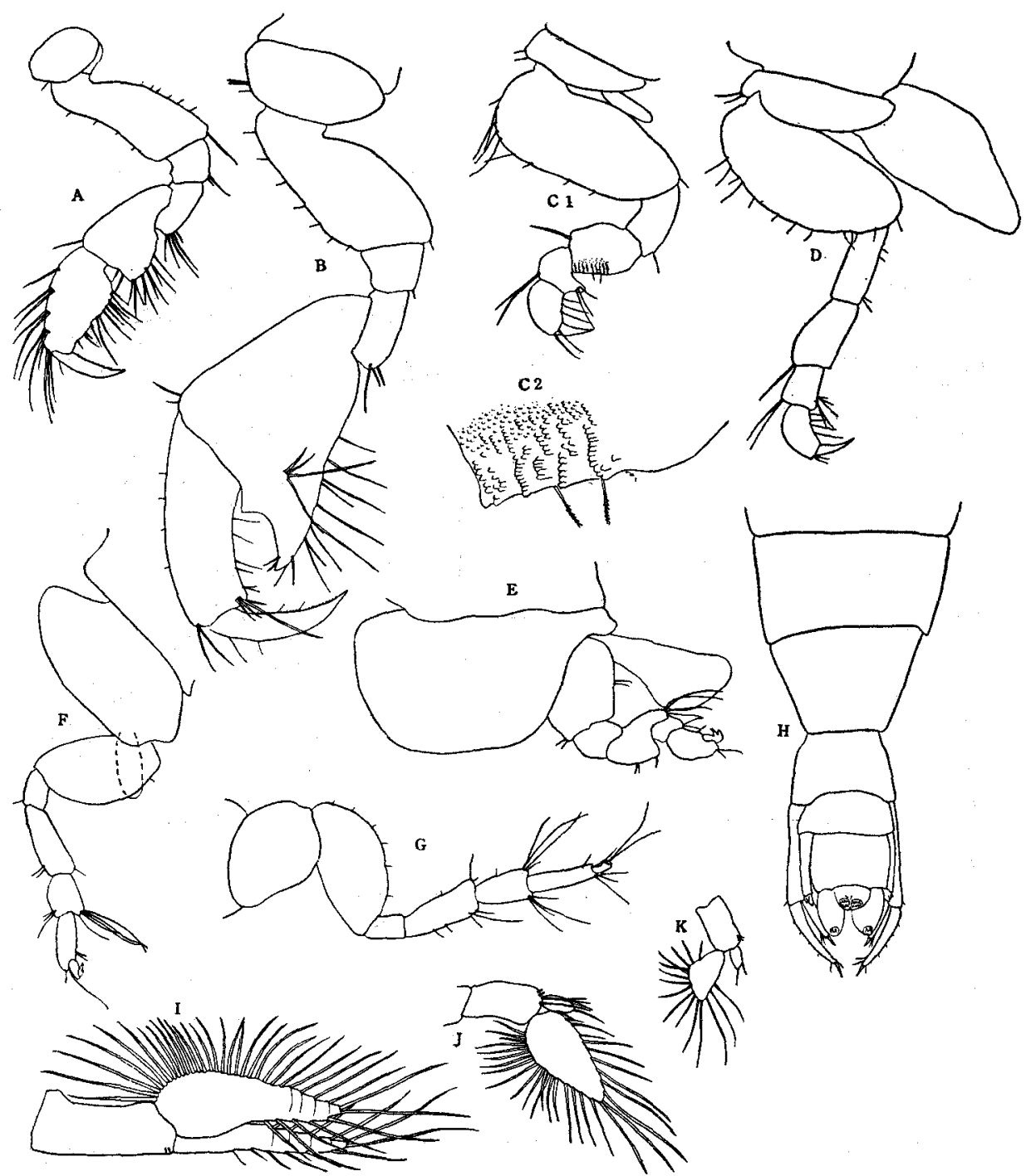

Text-fig. 2. Appendages of Form A. A, male gnathopod I ( $\times 48)$; B, male gnathopod II $(\times 48)$; C1, pereiopod III $(\times 48) ; \quad$ C2, 4 th article of pereiopod III $(\times 330) ; \quad$ D, pereiopod IV $(\times 48)$; $\mathrm{E}$, pereiopod V $(\times 48) ; \mathrm{F}$, pereiopod VI $(\times 48) ; \mathrm{G}$, pereiopod VII $(\times 48) ; \mathrm{H}$, caudal region I; uropod I $(\times 48)$; J, uropod II $(\times 48) ; \mathrm{K}$, uropod III $(\times 48)$; from Tanabe Bay, May 21, 1973. 


\section{Descriptions}

Since full descriptions have been made repeatedly in literatures (Stebbing, 1888, 1906), the following problematic characters are described for comparison. Colour pattern. Although the following descriptions are based on the materials in alcohol, their colour pattern well retains the living state. Form A from Tanabe Bay: antennae pale except the proximal part of 1 st peduncular article of antenna I, which coloured brown. Head and the following two to three pereionites and Ist as well as 2nd articles of pereiopod I-III also coloured, but gradually faded away to the posterior pereionites. Pleonites and urosomites perfectly colourless. Form A from Wakasa Bay: 1st peduncular article of antenna I coloured brown; the rest of antennae colourless. Body brownish. Only urosomites and distal articles of the pereiopods pale. Form B: antenna I and II with brown patches (Fig. 3). The similar pattern is seen in 5th and 6th articles of gnathopod I and II. Head

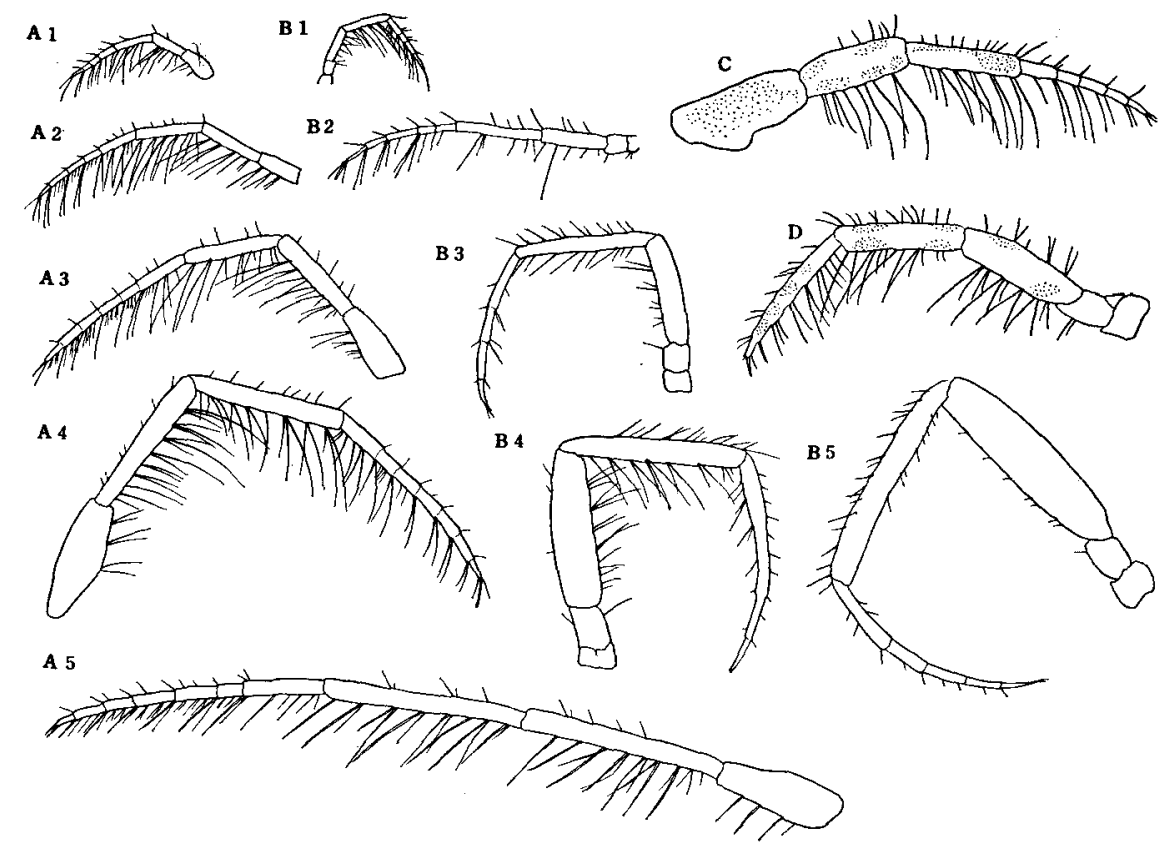

Text-fig. 3. A, antenna I of Form A $(\times 16.5) ;$ B, antenna II of Form A $(\times 16.5)$; C, antenna I of Form B $(\times 16.5)$; D, antenna II of Form B $(\times 16.5) ; 1,2.0 \mathrm{~mm} ; 2,3.0 \mathrm{~mm} ; 3,3.8 \mathrm{~mm}$; 4, $4.3 \mathrm{~mm} ; 5,7.0 \mathrm{~mm}$; C, D, $5.7 \mathrm{~mm}$; 1-5, from Tanabe Bay, May 21, 1973; C, D, Kushimoto, December 27, 1973.

heavily coloured brown and gradually faded out to the colourless pereionite VI. The posterior part pale.

As seen above, the colour pattern resembles between the two groups of specimens of Form A and differs between Form A and Form B. Since the tube has also brownish colour, the above-mentioned colouration may play mimic effect on the animal.

Body Shape. Form A has slenderer body shape than Form B. The ratio of the body 
Table 1. Body size and lengths of peduncular articles of antennae I and II.

\begin{tabular}{|c|c|c|c|c|c|c|c|c|}
\hline \multirow[t]{2}{*}{ Material } & \multirow{2}{*}{$\begin{array}{l}\text { Body } \\
\text { length } \\
(\mathrm{mm})\end{array}$} & \multirow[t]{2}{*}{ Sex } & \multicolumn{4}{|c|}{$\begin{array}{c}\text { Antenna I, } \\
\text { peduncular articles } \\
\text { length }(\mathrm{mm}) \text { \& length ratio }\end{array}$} & \multicolumn{2}{|c|}{$\begin{array}{c}\text { Antenna II, } \\
\text { peduncular articles } \\
\text { length (mm) }\end{array}$} \\
\hline & & & 1 & 2 & 3 & $3 / 1$ & 4 & 5 \\
\hline & 2.7 & $\$$ & 0.60 & 0.84 & 0.84 & 1.40 & 0.83 & 0.99 \\
\hline & 3.0 & \$ & 0.68 & 1.01 & 0.98 & 1.44 & 1.07 & 1.23 \\
\hline Form A, & 3.1 & 오 & 0.54 & 0.53 & 0.61 & 1.13 & 0.58 & 0.72 \\
\hline Wakasa & 4.1 & $\hat{\delta}$ & 0.86 & 1.29 & 1.32 & 1.53 & 1.22 & 1.56 \\
\hline \multirow[t]{10}{*}{ Bay } & 4.3 & 古 & 0.90 & 1.43 & 1.56 & 1.73 & 1.64 & 1.72 \\
\hline & 4.3 & 古 & 0.98 & 1.74 & 1.78 & 1.82 & 1.82 & 1.87 \\
\hline & 4.8 & $\hat{8}$ & 1.13 & 1.91 & 2.02 & 1.79 & 2.08 & 2.18 \\
\hline & 5.3 & $\hat{\delta}$ & 1.15 & 1.93 & 1.94 & 1.69 & 2.13 & 2.15 \\
\hline & 1.3 & & 0.27 & 0.26 & 0.28 & 1.04 & 0.31 & 0.36 \\
\hline & 1.5 & $\hat{\delta}$ & 0.32 & 0.37 & 0.38 & 1.19 & 0.43 & 0.50 \\
\hline & 1.5 & $\$$ & 0.34 & 0.37 & 0.38 & 1.12 & 0.39 & 0.48 \\
\hline & 1.5 & $\hat{\delta}$ & 0.36 & 0.40 & 0.39 & 1.08 & 0.46 & 0.48 \\
\hline & 1.6 & 占 & 0.37 & 0.42 & 0.41 & 1.11 & 0.47 & 0.55 \\
\hline & 1.7 & 오 & 0.28 & 0.33 & 0.37 & 1.32 & 0.39 & 0.45 \\
\hline Form A, & 1.7 & 우 & 0.40 & 0.35 & 0.31 & 0.78 & 0.43 & 0.50 \\
\hline Tanabe & 1.8 & 占 & 0.40 & 0.49 & 0.48 & 1.20 & 0.57 & 0.67 \\
\hline \multirow[t]{13}{*}{ Bay } & 1.9 & 우 & 0.32 & 0.32 & 0.35 & 1.09 & 0.37 & 0.41 \\
\hline & 2.0 & 今 & 0.44 & 0.53 & 0.52 & 1.18 & 0.57 & 0.70 \\
\hline & 2.1 & 占 & 0.47 & 0.58 & 0.57 & 1.21 & 0.65 & 0.74 \\
\hline & 2.3 & 우 & 0.33 & 0.28 & 0.30 & 0.91 & 0.42 & 0.47 \\
\hline & 2.3 & 우 & 0.41 & 0.38 & 0.45 & 1.10 & 0.41 & 0.53 \\
\hline & 2.5 & $\uparrow$ & 0.54 & 0.72 & 0.73 & 1.35 & 0.87 & 0.94 \\
\hline & 2.8 & 우 & 0.43 & 0.44 & 0.52 & 1.21 & 0.82 & 0.94 \\
\hline & 3.1 & 今 & 0.65 & 1.12 & 1.05 & 1.62 & 1.25 & 1.33 \\
\hline & 1.9 & & 0.44 & 0.31 & 0.34 & 0.77 & 0.39 & 0.39 \\
\hline & 2.0 & & 0.44 & 0.34 & 0.37 & 0.84 & 0.41 & 0.43 \\
\hline & 2.3 & $\hat{\delta}$ & 0.55 & 0.44 & 0.48 & 0.87 & 0.51 & 0.52 \\
\hline & 2.3 & $\hat{\sigma}$ & 0.56 & 0.44 & 0.48 & 0.86 & 0.50 & 0.53 \\
\hline & 2.5 & 우 & 0.54 & 0.41 & 0.47 & 0.87 & 0.50 & 0.54 \\
\hline \multirow[t]{6}{*}{ Form B } & 2.7 & 우 & 0.56 & 0.43 & 0.48 & 0.86 & 0.52 & 0.53 \\
\hline & 2.8 & $\hat{\jmath}$ & 0.54 & 0.50 & 0.57 & 1.06 & 0.62 & 0.64 \\
\hline & 2.9 & $\hat{\jmath}$ & 0.67 & 0.53 & 0.57 & 0.85 & 0.59 & 0.65 \\
\hline & 2.9 & 古 & 0.71 & 0.54 & 0.59 & 0.83 & 0.64 & 0.65 \\
\hline & 3.0 & 우 & 0.62 & 0.45 & 0.52 & 0.84 & 0.55 & 0.56 \\
\hline & 3.0 & 우 & 0.60 & 0.46 & 0.52 & 0.87 & 0.54 & 0.56 \\
\hline
\end{tabular}


length (from the tip of rostrum to the postero-median margin of pereionite VII) to body width (Width of pereionite III) ranges from 4 to 5 (mean $=4.6, \mathrm{n}=11$ ) in Form B. On the contrary, it varies from 5 to $6($ mean $=5.7, \mathrm{n}=17)$ in Form A from Tanabe Bay. It was difficult to measure the Wakasa Bay specimens exactly, because of the bad condition of preservation. However, they seem to be very much similar to the latter. This elongated shape of the body of Form A seems to be associated, to some extent, with the marked elongation of pereionite I and II in male, but in female only pereionite $\mathrm{V}$ elongated. These pereionites are never extended so much in Form B.

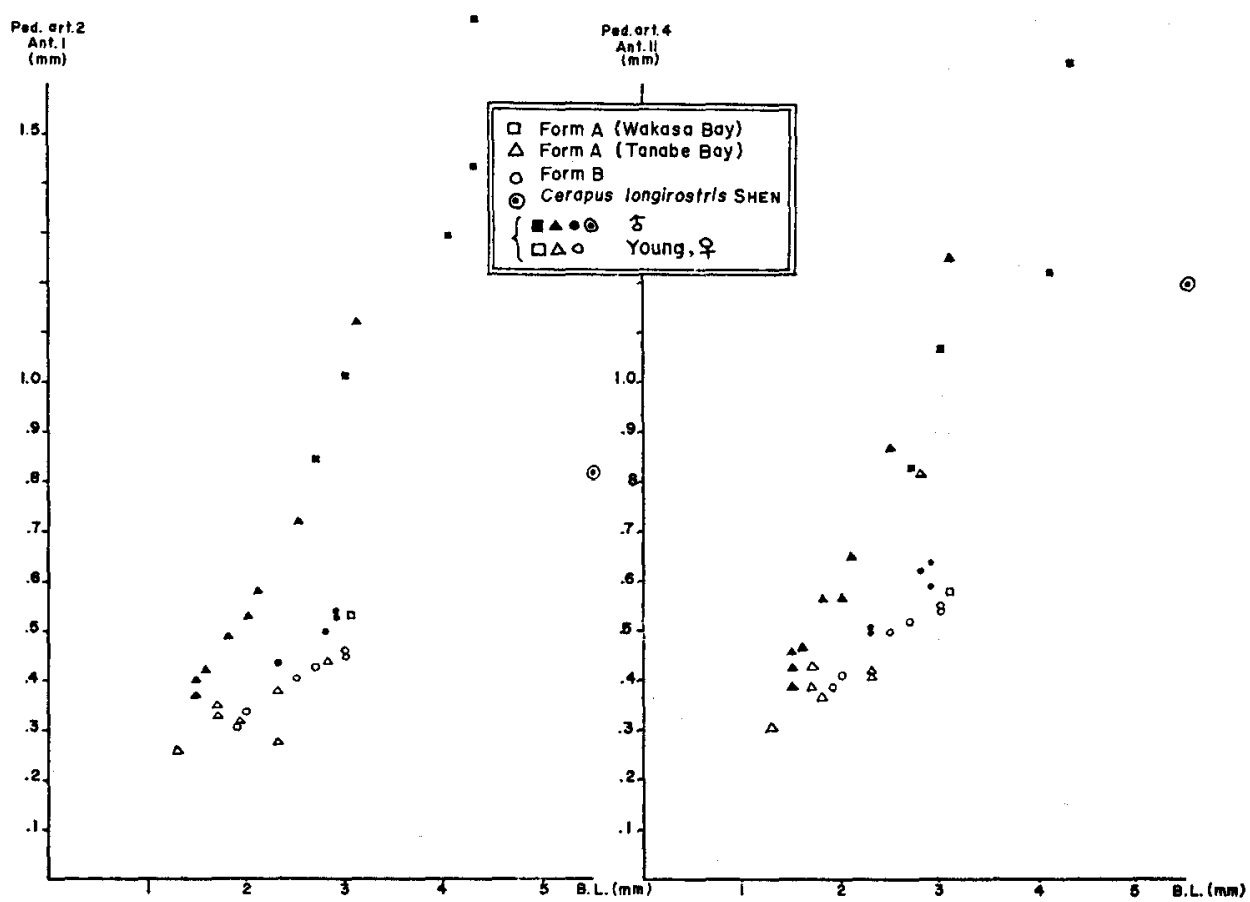

Text-fig. 4. Lengths of peduncular articles 2 and 4 of antennae I and II respectively, plotted against body length.

Length of Antennae. In addition to much elongated body, Form $\mathrm{A}$ has longer antennae than Form B. Length of peduncular articles of antenna I and II against body length are shown in Table I, as well as in Fig. 4. Males of Form A have decisively longer peduncular articles than those of Form B, while there is no distinct difference among females of three localities.

Male Gnathopod II. Since Barnard (1962) suggested the differences of this appendage in synonymized species to the mere difference of growth stage, gnathopods of various sizes of specimens from three localities are compared (Fig. 5). There exist some differences in 5th article among specimens from three localities. Namely, in smaller specimens of Form A, 5th article is much slender and the palmar margin is quite 
oblique. A tooth on the palmar margin is not conspicuous as compared with Form B. However, large specimen from Tanabe Bay has a prominent denticulated tooth on the palmar margin of 5 th article and denticulation on the site of 6 th article touching it. That prominent tooth is somewhat like the figures depicted by Stebbing (1910) for C. abditus, and by Shen (1936) for C. longirostris. There is no great difference between these two Forms and those figures by Bulycheva (1952) for C. erae, by Kunkel (1918) for C. tubularis, by Chilton (1892) for C. findersi which was synonymized with C. abditus by Barnard (1916), and by Smith (1880) for C. tubularis. Among
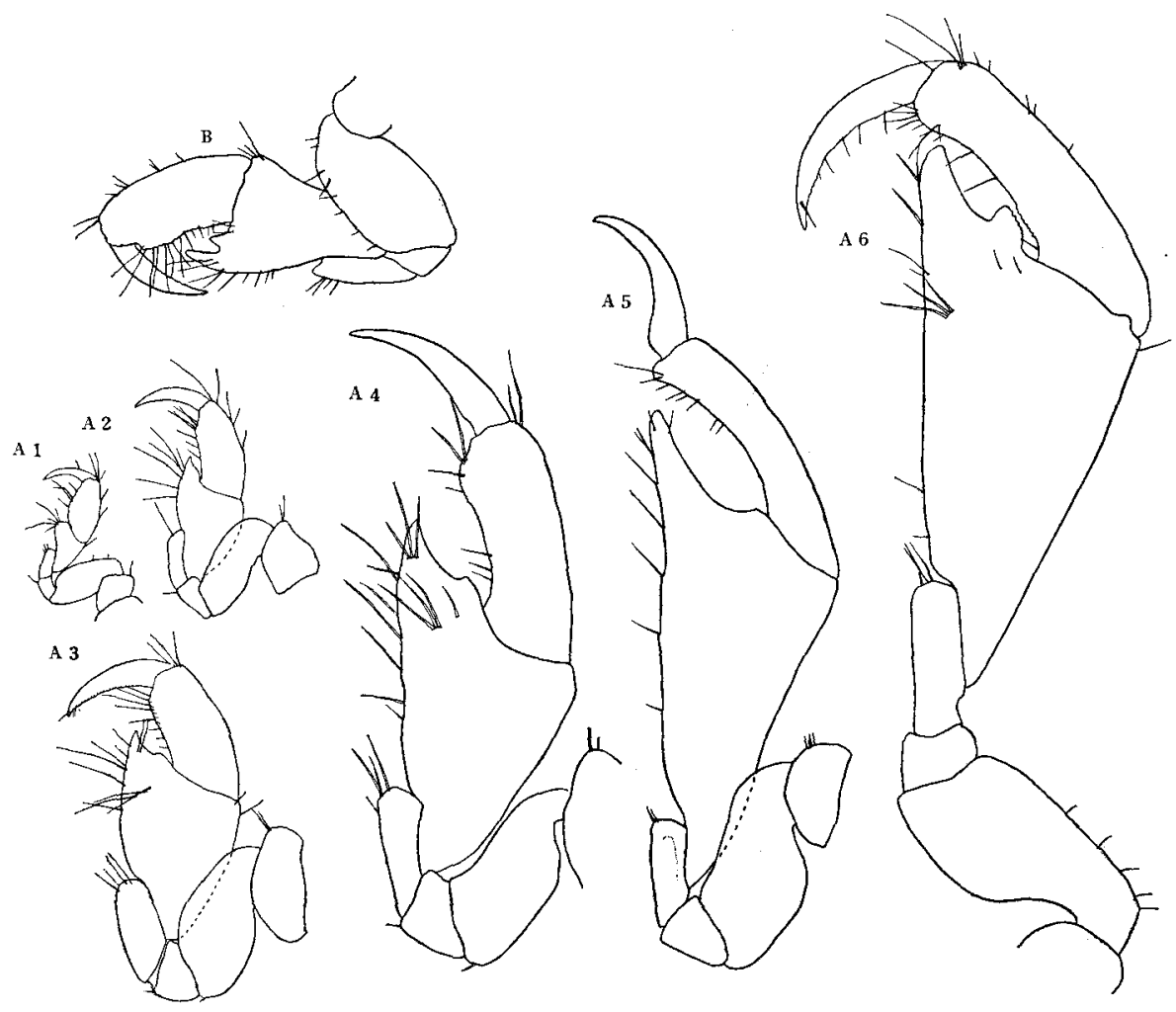

Text-fig. 5. A, male gnathopod II of Form A $(\times 48)$; B, male gnathopod II of Form B $(\times 32.5)$. $\mathrm{B}, 5.7 \mathrm{~mm} ; 1,2.0 \mathrm{~mm} ; 3,3.8 \mathrm{~mm} ; 4,4.0 \mathrm{~mm} ; 5,6.0 \mathrm{~mm} ; 6,7.0 \mathrm{~mm}$. B, Kushimoto, December 27, 1973; 1-3, 6, from Tanabe Bay, May 21, 1973; 4, 5 from Wakasa Bay, May 19, 1972.

them, C. erae is remarkably coincident with smaller specimen of Form A.

Pereiopod III. There is a bump on the hind margin of 5th article, and the surface of the hind parts of 4 th article has several transverse series of minute prominences in Form A. But neither of these ornamentations are seen in Form B (Fig. 6). This peculiarity of 5 th article of pereiopod III in Form A are only seen in C. erae Bulycheva, which Barnard (1962) regarded as "only varietal value". Since pereiopod III was seen engaged in building dwelling tube, I immagined the bump and the warts to 
have some function to make up the splendid tube of Form A. But, judging from the illustrations given with the descriptions on Cerapus species, species living in the splendid tube are not necessarily provided with the bump on the 5 th article. So it is still needed to be proved.

Tube. The tube of Form A is regularly cylindrical, and widened a little on one end. The colour is dark brown with pale cross stripes (Fig. 7). The tube is rather tuff, having leathery texture. The same is described on the tube in Kunkel (1918) and Stebbing (1906) for C. tubularis, Templeton (1836) for C. abditus, and Chilton (1892) for C. findersi.

In contrast with this, Form B carries their nest made of some pieces of algae and chaff (Fig. 7). Shen (1936) mentioned the nest of C. longirostris as "composed of chips or dead leaves and gelatinous fibres." This resembles most closely the abovementioned nest tube of Form B.

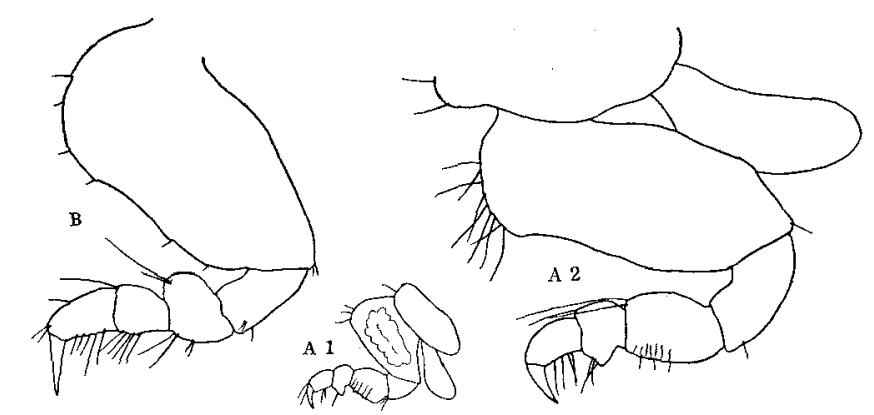

Text-fig. 6. A, pereiopod III of Form A ( $\times 48)$; B, pereiopod III of Form $B(\times 48) ; 1,2.0 \mathrm{~mm} ; 2,6.0 \mathrm{~mm} ; B, 5.7 \mathrm{~mm}$. 1, from Tanabe Bay, May 21, 1973; 2, from Wakasa Bay, May 19, 1972; B, from Kushimoto, December 27, 1973.

Habitat and Behavior. Form A has been collected on the sandy bottom, the depth of 5-10 m. According to Mr. Yanagisawa who made close observation on this animal in Tanabe Bay, the tubes were attached at one end to shell fragments or large sand grains on the bottom. The animals were concealing themselves in the tube, but exposing their antennae and anterior part of the body outside the tube. In the laboratory the animals usually anchored the tube to the bottom or wall of the glass vessel by the widened end. Occasionally they crawled about carrying the tube with them. Crawling was performed principally by gnathopod I, Very easily they changed their direction in the closely-fitted tube. When forced to quite its own tube, the animal tried to get into another tube in the immediate neighbourhood, but usually in vain, as it kicked out by the occupant. If they were disturbed, they easily took off from the substratum and swam around with tube. The mode of the swimming behavior of this animal seems to be unique in gammaridean Amphipoda. Both antennae are engaged in, but no pleopods (Fig. 8). They swim on their back by flapping the antenna I and II, the former vertically and the latter 
horizontally. They can move backwards or upwards. This mode of behavior remainds me of Caprellidea. Without tube, they only jerked their whole body blindly in the water.

Form B has been collected in the intertidal zone when the tide was low enough. They have been found in a restricted area where pieces of algae and chaff were accumulated in amount. In captivity, the same habit and behavior were observed as those of Form A. Some of them were forced to be deprived of their nests to see if they could make their tubes without rigid foreign materials. After two days, one of them constructed a short tube of detritus which was accumulated in the jar (Fig. 7). It was not so beautiful as that of Form A.

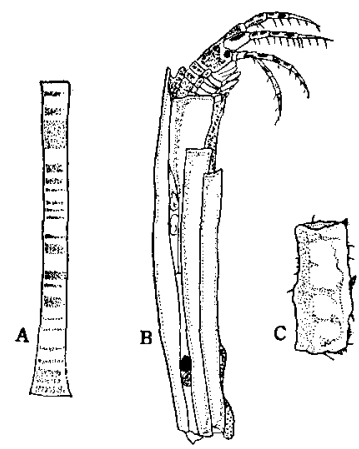

Text-fig. 7. A, tube of Form A $(\times 5) ; \mathrm{B}$, Form $\mathbf{B}$ in his nest $(\times 5)$; $\mathrm{C}$, a tube newly built by Form B, exposed outside the tube in the laboratory $(\times 5)$.
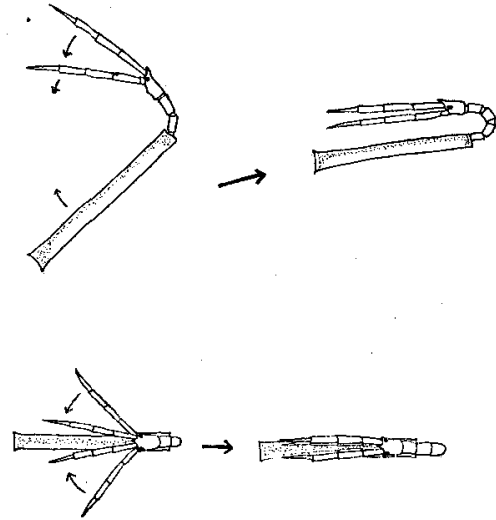

Text-fig. 8. Antennal beating in swim.

In all the three localities, they have not been collected regularly in the same place. Probably they form small patches and not distributed uniformly in the wide area.

Remarks. The genus Cerapus is probably one of the amphipod groups that are highly adapted to the tube-dwelling life. With morphological respect, Cerapus shows elongate antennae, reduction in coxae, loss of uropodal and telsonic structure, and depression of urosome. These modifications are said to have a relationship to domiciliary habits (Barnard, 1973). In addition, the splendid tube and the observed habit will reinforce the view.

Barnard (1958) listed the following eight species in this genus Cerapus; abditus, crassicornis, erae, longirostris, oppositus, polutovi, sismithi, and tubularis. But he (1962) later synonymized longirostris with abditus which, together with erae, is further synonymized with tubularis. Among the rest species, crassicornis, sismithi and oppositus compose an allied group by sharing distally widened peduncular article of antenna I. This article is said to serve as an operculum of the tube (Sars, 1895). C. polutovi 
stands apart from the resting species by 6th article of male gnathopod II, which has four prominent bumps. C. comparativus seems to be synonymous with $C$. polutovi. The described differences which discriminate the former species from the latter, that is, "form and proportions of the 6th joint, form and armarage of the palmar margin" of the Gnathopod I and II, could be size-dependent variations.

It is of no doubt that Form $A$ is closely allied to $C$. erae Bulycheva which was reported from the Japan Sea, whereas there are a few points of similarity which suggest that Form B represents $C$. longirostris Shen. These are: (1) the relative length of peduncular articles of antennae measured on the illustration depicted by Shen, fitted well to those of Form B (Fig. 4). (2) similar structure of tube, and (3) the comparative proximity of localities, i.e. C. longirostris is reported from Shangtung Peninsula in the Yellow Sea. But the former two characters are not diagnostic to $C$. longirostris Shen. With regards to relative length of peduncular articles of antennae, actual measurements on the specimens of $C$. tubularis and $C$. abditus are lacking for comparison. Thus, distinctive difference shown on this character between Form A and Form B cannot be evaluated as to attributing either Form to either "species". In addition, the relative length seems to be an inappropriate character in defining species, since it varies greatly with growth, as seen in the present specimens. As to tube, the difference of the material seems to reflect the difference of the available material. The fact that Form B has made tube without algal substances, though in experimental condition, may support this view. As to bump on the 5th article of pereiopod III in Form A, it is peculiar to Form A and $C$. erae. But it should be assigned only varietal value, when compared with the differences shown among the congeneric "good" species.

As a result of these examinations, it seems appropriate that the present two Forms are regarded as varieties, fairly distinct, of the same species $C$. tubularis Say sensu Barnard, for one of which, Form A, a new variety, Cerapus tubularis var. erae (Bulycheva), is now proposed.

\section{REFERENCES}

Barnard, K. H. 1916. Contributions to the crustacean fauna of South Africa. 5. The Amphipoda. Ann. S. Afr. Mus., Vol. 15, pp. 105-302, Pls. 26-28.

- - 1932. Amphipoda. Discovery Reports, Cambridge, Vol. 5, pp. 1-326, Pl. 1, 174 text-figs.

Barnard, J. L. 1958. Index to the families, genera, and species of the marine gammaridean Amphipods (Crustacea). Allan Hankock Found. Publ., Occ. Paper, No. 19, pp. 1-146.

1962. Benthic marine Amphipoda of southern California. 1. Families Aoridae, Photidae, Ischyroceridae, Corophiidae, Podoceridae. Pacific Naturalist, Vol. 3, no. 1, pp. 13-72, 32 text-figs.

1969. The families and genera of marine gammaridean Amphipoda. Smithsonian Inst., U. S. Nat. Mus., Bull. 271, pp. i-vi+1-535.

1973. Revision of Corophiidae and related families (Amphipoda). Smithsonian Contr. Zool., no. 151, pp. 1-27, 1 text-figs.

Bate, C. S. and Westwood, J. O. 1863. A history of British sessile-eyed Crustacea. London. 507 pp. Bulycheva, A. I. 1952. Novye vidy bokoplavov (Amphipoda, Gammaridea) iz Japonskogo Morja. 
Akad. Nauk. SSSR, Trudy Zool. Inst., Vol. 12, pp. 195-250, 39 text-figs. (In Russian).

Chilton, Ch. 1892. On a tubicolous Amphipod from Port Jackson. Rec. Austr. Mus., Vol. 2, no. 1, pp. 1-6, P1. 1.

Della Valle, A. 1893. Gammarini del Golfo di Napoli. Fauna und Flora des Golfes von Neapel, Vol. 20, pp. 1-948, Atlas, Explanation of Plates and Plates 1-61.

Gurjanova, E. 1951. Bokoplavy morej SSSR i sopredel'nykh vod (Amphipoda-Gammaridea). Opred. po Faune SSSR, Akad. Nauk SSSR, Vol. 41, 1029 pp., 705 text-figs. (In Russian).

Kudrjashov, V. A. 1973. New Amphipod species (Gammaridea) from the intertidal zone of the Kurile Island. Zool. Zh., Vol. 34, pp. 364-371. (In Russian).

Kunkel, B. W. 1918. The Arthrostraca of Connecticut. Bull. Conn. State Geol. N. H. Survey, Hartford, No. 26, pp. 1-261.

Nagata, K. 1965. Gammaridean Amphipoda of the Seto Inland Sea. III. Publ. Seto Mar. Biol. Lab., Vol. 8, no. 4, pp. 291-326, 18 text-figs.

Pirlot, J. M. 1938. Les Amphipodes de l'expédition du Siboga. Deuxième partie. Les Amphipodes Gammarides. III. Les Amphipodes littoraux, 2. Familles des Dexaminidae, Talitridae, Aoridae, Photidae, Amphithoidae, Corophiidae, Jassidae, Cheluridae et Podoceridae. SibogaExped. Mon. 33f, pp. 329 359, figs. 147-161.

Sars, G. O. 1895. Amphipoda. An account of the Crustacea of Norway, I. Text, pp. i-viii +1-711, Plates, Pls. 1-240 + Suppl. Pls 1-8.

Shen, C. J. 1936. Description of a new tube-dwelling amphipod collected on the coast of Shantung Peninsula. Bull. Fan Mem. Inst. Biol. (Zool.), Vol. 6, no. 6, pp. 265-273, 5 figs.

Smith, S. I. 1880. On the amphipodus genera, Cerapus, Unciola, and Lepidactylis, described by Thomas Say. Trans. Conn. Acad., Vol. 4, pp. 269-277. Pl. 1.

Stebbing, T. R. R. 1888. Report on the Amphipoda collected by H. M. S. "Challenger" during the years 1873-1876. Rept. Sci. Res. Voy. Challenger, Zool., Vol. 29, Text, pp. 1-1737, Plates, Pls. 1-210.

1906. Amphipoda I. Gammaridea. Schulze's "Das Tierreich", Lief. 21, Berlin, pp. xxxix $+806,127$ text-figs.

1910. Crustacea. Part 5, Amphipoda. Sci. Res. Trawling Exped. H. M. C. S. "Thetis". Mem. Austr. Mus., Vol. 2, no. 12, pp. 567-658, Pls. 47-60. 